\title{
Evaluation of Fungicides, Botanicals and Trichoderma spp. against Wilt of Chickpea Caused by Fusarium oxysporum f. sp. ciceri
}

\author{
Sonika Jamwal $^{1 *}$, Anamika Jamwal ${ }^{2}$, A.C. Jha ${ }^{1}$, Reena ${ }^{1}$, Upma Dutta ${ }^{3}$, \\ Anil Kumar ${ }^{1}$, Neeraja Sharma ${ }^{4}$, Sanjeev Kumar ${ }^{1}$ and Ajay Kumar ${ }^{2}$ \\ ${ }^{1}$ Advance Centre for Rainfed Agriculture, India \\ ${ }^{2}$ KVK Kathua, India \\ ${ }^{3}$ Division of Microbiology, Basic Sciences Main Campus Chatha, India \\ ${ }^{4} \mathrm{KVK}$ Samba, India \\ *Corresponding author
}

\begin{tabular}{|c|c|}
\hline & A B S T R A C T \\
\hline $\begin{array}{l}\text { Ke y w or d s } \\
\text { Fusarium } \\
\text { oxysporum f. sp. } \\
\text { ciceri, } \\
\text { Phyto-extracts, } \\
\text { Trichoderma spp. }\end{array}$ & \multirow{3}{*}{$\begin{array}{l}\text { All the fungicides at different concentrations were significantly inhibitory } \\
\text { to the fungal growth as compared to control. The cent percent growth } \\
\text { inhibition was recorded in carbendazim and Propiconazole at } 100 \text { to } 1000 \\
\text { ppm). The next effective fungicide was Metalaxyl ( } 500 \text { to } 1000 \mathrm{ppm} \text { ), } \\
\text { benlate ( } 750 \text { and } 1000 \mathrm{ppm} \text { ) which were also inhibited cent percent growth } \\
\text { of fungus. Trichoderma harzianum isolate } 1 \text { (Jammu) showed strong } \\
\text { antagonistic effect, followed by T. harzianum isolate } 3 \text { (Kathua). The } \\
\text { phytoextracts screened in vitro by poisoned food technique against } \\
\text { Fusarium oxysporum f. sp. ciceri revealed that Azadirachta indica leaves } \\
\text { extract showed maximum growth inhibition of fungus followed by Allium } \\
\text { sativum. }\end{array}$} \\
\hline Article Ir & \\
\hline $\begin{array}{l}\text { Accepted: } \\
\text { 12 October } 2017 \\
\text { Available Online: } \\
10 \text { December } 2017\end{array}$ & \\
\hline
\end{tabular}

\section{Introduction}

Chickpea (Cicer arietinum) is one of the most important pulse crop cultivated and consumed in India. In India chickpea accounts for about $45 \%$ of total pulses produced in the country. Crop duration is about 90 to 120 days. Chickpea is the third most important pulse crop after dry bean and peas produced in the world. India is the largest producer, with about 8 million tonnes accounting of about $70 \%$ of total world production (AICRP chickpea). Among the soil borne diseases of chickpea, wilt diseased caused by Fusarium oxysporum f. sp. ciceri is an important soil borne disease in Jammu division. Considering seriousness of the disease, the present investigation was carried out.

\section{Materials and Methods}

The required quantities of each test fungicides were put in the conical flask containing $100 \mathrm{ml}$ molten PDA medium so as to get required concentration in ppm. The flask containing poisoned medium was well shaken to 
facilitate uniform mixture of fungicides and $20 \mathrm{ml}$ was poured in each sterilized petriplates. Further standard procedure was adopted on $\%$ growth inhibition of pathogen. Similar procedure was adopted for testing bioagents. Healthy fresh plant parts i.e., leaves/ bulbs/rhizomes were taken washed thoroughly with fresh water and finally rinsed with sterilized distilled water. Fifty gram of plant parts was grinded in a mixture by adding $100 \mathrm{ml}$ acetone, filtered through double-layers muslin cloth and tested as per the above techniques. The studies were carried out under in vitro conditions. All the isolation and inoculation work was carried out in laminar air flow under aseptic condition. The platform of laminar air flow was sterilized by glowing ultraviolet light for half an hour prior to commencement of work.

The working surface of laminar flow and side glasses were surface sterilized with denatured spirit. Moreover, other such necessary care was taken to maintain and carryout work under aseptic/conditions. The glass wares such as petriplates, beakers and test tubes were sterilized in hot air oven at $180^{\circ} \mathrm{C}$ for 1 hour and media were sterilized in autoclave at 121.6lbs/inch ${ }^{2}$ for 15 minutes.

Isolation of Fusarium oxysporum f. sp. ciceri

Chickpea plant showing typical wilt symptoms were collected from the farmer's field of Rayean village from Samba district. The repeated isolations were made to isolate pathogen from wilted plants showing browning of vascular tissue. The roots and stem of infected plants were washed in running tap water to remove soil before isolation to avoid contamination.

The roots were cut into small bits of the size $2.5 \mathrm{~mm}$ with sterilized blade. These bits were then surface sterilized with 0.1 percent mercury chloride. Each bit was blot dried and four bits placed on the each prepoured solidified potato dextrose agar (PDA) plated. These plates were then incubated at $27^{0} \mathrm{C}$ for seven days. The fungal growth was transferred to the plates of PDA

\section{Purification, identification and maintenance of pathogen}

F. $o$. f. sp. ciceri culture isolated from the wilted chickpea plant were purified from single spore method and identified by the colony characteristics appeared as white cottony growth on PDA medium which became felted and wrinkled in old culture colonies. By microscopically their morphological characters such as abundance of micro and fewer macro conidia were analysed. Microconidia were oval to cylindrical, straight to curved and measured 2.5-3.5x 5-11um and were poured on short, unbranched monophialides. Macroconidia borne on branched conidiophores, were thin walled, 3.5-4.5 x 2.5- 6.5 um (Trivedi and Rathi, 2015).

The pathogen was subculture on PDA slants and allowed to grow at $27^{\circ} \mathrm{C}$ temperature for 10 days. Obtained culture was stored in refrigerator at $40 \mathrm{C}$ and were sub cultured periodically once in a month.

\section{Results and Discussion}

Results revealed that all the systemic fungicides were capable of inhibiting the growth of the test fungus at different concentrations as compared to check. Carbendazim and Propiconazole proved be the most effective inhibiting cent percent growth of the test fungus at all the concentrations (100, 250, 500, 750 and $1000 \mathrm{ppm}$ followed by Metalaxyl (500, 750 and 1000ppm) and benlate (750 and 1000ppm). 
Table.1 Evaluation of fungicides against Fusarium oxysporum f. sp. ciceri at different concentrations

\begin{tabular}{|c|c|c|c|c|c|}
\hline $\begin{array}{l}\text { Systemic Fungicides } \\
\text { (PPM) }\end{array}$ & \begin{tabular}{|l|} 
Growth \\
Inhibition \\
$(\%)$
\end{tabular} & $\begin{array}{l}\text { Non systemic } \text { Fungicides } \\
(\text { PPM) }\end{array}$ & $\begin{array}{l}\text { Growth } \\
\text { Inhibition }(\%)\end{array}$ & $\begin{array}{l}\text { Mix fungicides } \\
\text { (PPM) }\end{array}$ & $\begin{array}{l}\text { Growth } \\
\text { inhibition }(\%)\end{array}$ \\
\hline \multicolumn{2}{|l|}{ Metalaxyl } & \multicolumn{2}{|c|}{ Mancozeb (Diathane M-45 75WP) } & \multicolumn{2}{|c|}{ Carboxin + Thiram (Vitavax power 75WP) } \\
\hline 100 & 92.1(74.24) & 500 & $32.1(34.85)$ & 100 & $52.2(46.55)$ \\
\hline 250 & $93.3(78.21)$ & 1000 & $59.4(50.71)$ & 250 & $88.3(70.46)$ \\
\hline 500 & $100.0(88.15)$ & 1500 & $65.5(54.39)$ & 500 & $91.7(73.80)$ \\
\hline 750 & $100.0(88.15)$ & 2000 & $77.2(61.84)$ & 1000 & $100.0(88.15)$ \\
\hline 1000 & $100.0(88.15)$ & 2500 & $82.7(69.81)$ & 1500 & $100.0(88.15)$ \\
\hline \multicolumn{2}{|c|}{ Carbendazim (Bavistin 50WP) } & Carboxin (Kavach 75 WP) & & \multicolumn{2}{|c|}{ Carbendazim(12WP) +Mancozeb (63WP) } \\
\hline 100 & $100.0(88.15)$ & 500 & $33.2(35.51)$ & 100 & $32.5(35.08)$ \\
\hline 250 & $100.0(88.15)$ & 1000 & $46.5(43.27)$ & 250 & $100.0(88.15)$ \\
\hline 500 & $100.0(88.15)$ & 1500 & $52.4(46.67)$ & 500 & $100.0(88.15)$ \\
\hline 750 & $100.0(88.15)$ & 2000 & $53.3(47.18)$ & 1000 & $100.0(88.15)$ \\
\hline 1000 & $100.0(88.15)$ & 2500 & $52.7(46.86)$ & 1500 & $100.0(88.15)$ \\
\hline \multicolumn{2}{|l|}{ Propiconazole (Tilt) } & Thiram & & \multicolumn{2}{|c|}{ Metalaxyl (8WP) + Mancozeb (64WP) } \\
\hline 100 & $100.0(88.15)$ & 500 & $66.0(54.61)$ & 100 & $21.3(27.82)$ \\
\hline 250 & $100.0(88.15)$ & 1000 & $80.1(63.88)$ & 250 & $31.4(34.40)$ \\
\hline 500 & $100.0(88.15)$ & 1500 & $88.2(70.35)$ & 500 & $38.6(38.71)$ \\
\hline 750 & $100.0(88.15)$ & 2000 & $88.4(70.52)$ & 1000 & $65.0(53.01)$ \\
\hline 1000 & $100.0(88.15)$ & 2500 & $88.70(70.79)$ & 1500 & $66.4(54.88)$ \\
\hline Benlate & & Captan (Captaf 75WP) & & Thiram +Mancozeb & \\
\hline 250 & $90.6(72.68)$ & 500 & $66.0(54.66)$ & 250 & $93.0(75.20)$ \\
\hline 500 & $82.7(65.78)$ & 700 & $94.3(76.92)$ & 1500 & $100.0(88.15)$ \\
\hline 750 & $100.0(88.15)$ & 1000 & $100.0(88.15)$ & 1000 & $100.0(88.15)$ \\
\hline 1000 & $100.0(88.15)$ & & & & \\
\hline Treatment & Conc. TXC & Treatment & Conc. T\&C & Treatment & Conc. TxC \\
\hline S.E. \pm 0.08 & 0.090 .17 & 0.08 & 0.090 .19 & 0.20 & 0.260 .45 \\
\hline C.D. $(=0.05) 0.21$ & 0.240 .49 & 0.24 & 0.270 .53 & 0.58 & 0.751 .30 \\
\hline
\end{tabular}

*Average of three replication; Figures in parenthesis are arc sine transformed values. 
Table.2 In vitro efficacy of plant extracts against Fusarium oxysporum f. sp. cicero

\begin{tabular}{|l|l|l|l|l|}
\hline Plant extracts & \multicolumn{2}{l|}{$\begin{array}{l}\text { Percent inhibition of mycelial growth at different } \\
\text { concentration (percent) }\end{array}$} & Mean \\
\hline & $\mathbf{5 \% ~ 1 0 \% ~ 1 5 \%}$ & \\
\hline Azadirachta indica (Neem) & $35.64(36.65)$ & $46.90(43.22)$ & $58.15(49.69)$ & 56.33 \\
\hline Daturastramonium(Daturas) & $25.40(30.26)$ & $33.51(33.37)$ & $41.61(40.17)$ & 42.22 \\
\hline Allium sativum (Garlic) & $30.17(33.32)$ & $40.21(39.35)$ & $50.24(45.14)$ & 48.18 \\
\hline OcimumtenuiflorumTulsi) & $21.54(27.65)$ & $25.90(30.59)$ & $30.25(33.37)$ & 35.16 \\
\hline Control & $0.00(0.00)$ & $0.00(0.00)$ & $0.00(0.00)$ & \\
\hline $\mathrm{SEm} \pm$ & 0.59 & 0.56 & 0.66 & \\
\hline $\mathrm{CD}(\mathrm{P}=0.05)$ & 1.83 & 1.73 & 2.04 & \\
\hline
\end{tabular}

*Average of four replications**Figures given in parenthesis are angular transformed values.

Table.3 Antagonistic efficacy of Trichoderma spp. against wilt of chickpea under in vitro condition

\begin{tabular}{|l|l|}
\hline Antagonists & Growth inhibition $\mathbf{( \% )}$ \\
\hline Trichodermaharzianum isolate 1(Jammu) & $81.42(64.82)$ \\
\hline Trichodermaharzianum isolate 2 (Samba) & $72.3(58.56)$ \\
\hline Trichodermaharzianum isolate 3 (Kathua) & $77.4(61.94)$ \\
\hline Trichodermaviride isolate 1 (Jammu) & $74.0(59.64)$ \\
\hline Trichodermaviride isolate 2 (Samba) & $67.6(55.65)$ \\
\hline Trichodermaviride isolate 3 (Kathua) & $63.8(53.31)$ \\
\hline Trichodermavirens isolate 1 (Jammu) & $66.0(54.66)$ \\
\hline Trichodermavirens isolate 2 (Samba) & $70.7(57.53)$ \\
\hline Trichodermavirens isolate 3 (Kathua) & $71.1(57.78)$ \\
\hline Control & $0.0(4.05)$ \\
\hline S.E.m \pm & 0.29 \\
\hline C.D. $(\mathrm{P}=0.05)$ & 0.83 \\
\hline
\end{tabular}

*Average of three replication ** Figures in parenthesis are arc sine transformed values.

Carbendazim and Mancozeb at 250, 500, 1000 and $1500 \mathrm{ppm}$ concentrations were found most effective. Gupta et al., (2014) found that carbendazim were most effective at higher doses against fungus in vitro. Singh and Singh (2006) found that carbendazim and mancozeb completely inhibited the fungal growth in vitro at higher. Carboxin and thiram at 1000 , $1500 \mathrm{ppm}$ were cent percent effective. Thiram + Mancozeb at 1500 and 1000ppm showed effective inhibitory effects. Among the nonsystemic fungicides, Captan proved to be the most effective in inhibiting cent percentmycelial growth at 1000, 2000 and 2500ppm concentrations followed by Thiram at $2500 \mathrm{ppm}(88.70 \%)$ inhibition. Similarly
Nikam et al., (2007) reported that Thiram $(0.15 \%)+$ carbendazim $(0.1 \%)$ is proved to be the most effective against Fusarium oxysporium f. sp. cicerias shown in table 1 .

\section{In vitro effect of Plant extract against Fusarium oxysporum f. sp. ciceri}

Effect of plant extracts was tested at 5, 10, and 15 percent concentration against inhibition of mycelial growth of Fusarium oxysporum f. sp. ciceri by poison food technique. The Azadirachta indica leaf extract was found significantly superior in inhibiting the mycelial growth $(56.33 \%)$, followed by Allium sativum love extract (48.18\%) and 
Daturastra monium (42.22). Ocimum tenuiflorum leaf extract was found least effective $(35.16 \%)$ against inhibition of mycelial growth of the fungus. As the concentration of plant extracts increased, the inhibition of test fungus decreases (Table 2). Similarly Kumar et al., (2012) evaluated 17 plant extracts and 7 completely inhibited the mycelial growth in vitro. Similar results were found by B. D. S. Nathawat and Mahindra (Pratap (2014). Sahani and Saxena (2008) reported that the seeds treated or soaked in Azadirachta indica (seed) extracts were the most effective for Fusarium oxysporum and significantly increased seed germination.

In vitro efficacy of Trichoderma spp against wilt of chickpea caused by Fusarium oxysporum f. sp. ciceri

Out of nine antagonists tested, Trichoderma harzianum isolate 1 (Jammu) showed significantly maximum growth inhibition $81.42 \%$ followed by $T$. harzianum isolate 3 (Kathua) as $77.4 \%$ growth inhibition as compared to control (Table 3). Mishra et al., 2012 also reported almost similar result on groundnut. Trichoderma viride isolate 1 (Jammu) showed $74.0 \%$ inhibition, Trichoderma virens isolate 3 (Kathua) inhibited $71.1 \%$ test fungus.

\section{References}

http://www.aicrpchickpea.res.in/

Kumar, P., and Mane, S. S. (2017), Efficacy of fungicides and biocontrol agents against Fusarium oxysporum f. sp. ciceri. Int. J. Curr. Microbial. App. Sci, 6(3): 1450 - 1455

Kumar, Rajendra, Jeewa Ram, LalitChhata and B. B. L. Thakore (2012). Evaluation of plant extracts against Pythium aphanidermatum inciting damping off of tomato. Ann. Pl. Protec. Sci. 20:181183.

Mishra, Divakar, A. A. Lal and Sobita Simon (2012). Efficacy of Trichoderma spp. with and without fungicides against tikka disease of groundnut. Ann. Pl. Protec. Sci. 20:492-493.

Nathawat, B. D. S. and Mahendra Pratap (2014). Evaluation of fungicides, botanicals and Trichoderma spp. against collar rot of groundnut (Arachis hypocraea L.) caused by Aspergillus niger van Tiegham. Ann. Pl. Protec. Sci. 22(2):382-385.

Nikam, P. S., Jagtap G. P. and Sonatakke, P. L. (2007), Management of chickpea wilt caused by Fusarium oxysporum f. sp. ciceri. African Journal of Agricultural Research Vol. 2 (12), pp. 692-697.

Sahani, R. K. and A, R. Saxena (2008). Efficacy of extracts of medicinal plants against Fusarium oxysporum f. sp. pici. Ann. Pl. Protec. Sci. 16:534-535.

Trivedi, L., and Rathi, Y. P. S. 2015. Detection of seed mycoflora from chickpea wilt complex seedborne Fusarium oxysporum f. sp. ciceri diseased seeds. World J. Pharmacl, Sci., 4(9): 1242-1249.

\section{How to cite this article:}

Sonika Jamwal, Anamika Jamwal, A.C. Jha, Reena, Upma Dutta, Anil Kumar, Neeraja Sharma, Sanjeev Kumar and Ajay Kumar. 2017. Evaluation of Fungicides, Botanicals and Trichoderma spp. against Wilt of Chickpea Caused by Fusarium oxysporum f. sp. ciceri. Int.J.Curr.Microbiol.App.Sci. 6(12): 1389-1393. doi: https://doi.org/10.20546/ijcmas.2017.612.155 